\title{
Os Dias Joaninos
}

NO norte do Brasil chega o mès de junho e todo o mundo sente a presença de outra pessôa no lar, nas casas-grandes e nas senzalas, nos engenhos e nas fazendas, nas mansões e nos mocambos. Estam a chegar os grandes dias 23 e 24 do mês quando, recebido com o esplendor de foguetes, balóes e tiros, se tornará pessôa da família brasileira o bom São João Batista.

Ninguém o desconhece, êste realizador de casamentos e de boas safras, e todo cristão, através das festividades religiosas, está pronto para recebê-lo. Nos grandes dias do santo a firme crença nos seus milagres reune democràticamente, alegremente, no solar das fazendas e nos alpendres das casas-grandes, empregados e patrões, feitores e trabalhadores.

Merece destaque o caráter alegre dessas comemorações. Até em pleno sertão preparam-se festejos. Asendem-se grandes fogueiras ros terreiros de antigos casarões, revelando que na familia existe pessôa de nome igual ao do santo ou pelo menos dum devoto dêle. Convidam-se as famílias dos arredores, dos engenhos próximos. São chamados tocadores improvisados para a "festança" que vêm conduzindo seus instrumentos rústicos, violóes, violas, pandeiros, caracaxás, réco-récos, ganzás, triângulos — todos enfeitados de fitas multicôres.

Os grupos de gente alegre e expansiva se juntam em volta das fogueiras para ouvir as canções rurais entoadas por algum cantor anônimo. Assa-se milho verde, contam-se anedotas ou pilhérias acerca dos noivos, ou tiram-se "sortes" sempre em redor do futuro casório. Nos patamares, pelas salas da casa-grande, espalham-se os convivas, aguardando con ansiedade a hora mágica e misteriosa: meia-noite. 
Chega, e se dirigem todos para o rio. Conduzem tições de fogueira, pequenos balốes de muitas côres, ramos de jasmins aromáticos, galhos de arruda e flores silvestres tecidos em corôas. E durante a caminhada cantam:

\author{
São João foi tomar banho \\ Com vinte e cinco donzelas; \\ As moças caíram nàgua, \\ São João caíu com elas.
}

Como o seu apóstolo purificou a carne de Jesus nas águas do Jordão, êles se livrarão das suas culpas também.

Depois a festa continua e se divertem com o ruido de fogos que estrondam. Os foguetes riscam o céu noturno como se tivessem o desejo de seduzir do seu sono o bom santo. Só não o consegue a multidão devota porque o Senhor tem arranjado aquilo de outra maneira. Segundo dizem os velhos, São João alguma vez indicou a Jesus que queria descer à terra para participar numa destas festas. O Criador, receioso de que o santo ficasse perdido pelas seduções do mundo e não voltasse ao céu, the ordenou um sono profundo.

Nem o luzeiro, nem os tiros de bacamares e ronqueiras, nem os estouros dos foguetes arrogantes conseguem acordá-lo do seu inocente sono. São João continua dormindo emquanto os seus devotos se divertem, comendo cangicas, pamonhas, pés-de-moleque, milho assado, requeijões e licores. Emquanto tiram "sortes" e se deixam envolver pela feitiçaria lírica das adivinhações, dos papelitos que sobrenadam em copos cheios dàgua anunciando futuros casórios, o santo dorme e dorme. Só depois de quarenta e oito horas é que acorda e pergunta, ainda sonolento, a su mãe, a esposa de Zacarias, a prima carnal de Nossa Senhora:

-Minha mãe, qual é o meu dia?

-Meu filho, já se passou.

-Uma noite tão bonita

Minha mãe não me acordou!

Um dos mais lindos mistérios dessa noite é o que gira em torno duma flor extranha, transparente, e esbranquiçada, que obre só uma vez no ano, na véspera de São João. É a arruda, misteriosa e bela, que nenhum feiticeiro, por mais experiente e iniciado na magia negra, a pode ver. Para os crentes, dos quais o santo é advogado, tem a 
graça poderosa de desfazer os piores sortilégios e malefícios. É o presente favorito que da o namorado ou noivo a sua bem amada. Se morre a flor dentro da semana morrerá também o seu amor. Então dirá o coitado namorado nas palavras duma canção velha:

Eu plantei um pé de arruda veio o diabo e carregou.

Lê-1ề-ồ-ô.

Fizeste o mesmo comigo:

veio um outro e te levou.

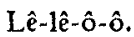

Ainda que, às vezes, se perder assim o amor, nunca se perderá o povo rural a suta devoção para o seu santo. Cada ano virá junho, virão as festas, e as adivinhações revelarão outra vez aos jovens $\cdot$ o nome do seu verdadeiro amor.

Virão os dias joaninos e estará de volta entre a sua família o santo bem brasileiro, São João.

ERNest R. MoOre, Oberlin College. 
